УДК 342.56:375

DOI https://doi.org/10.32849/2663-5313/2020.2.32

Ганна Васіна,

здобувач

Науково-дослідного інституту публічного права

\title{
ІСТОРИЧНІ I ПРАВОВІ АСПЕКТИ ВИТОКІВ АДМІНІСТРАТИВНОГО ПРАВА УКРАЇНИ ТА ІСПАНІї
}

У статті здійснена компаративістична характеристика історичних і правових аспектів витоків адміністративного права Украӥни й Іспанії. Виявлено й узагальнено, що в останні сто років Іспанія й Украйни пройшли складний і дещо схожий шлях державного будівниитва та розвитку теорії $i$ практики адміністративного права. Однак Іспанія розпочала його на шістнадиять років раніше й $у$ більш слушний момент (1975 р.). Це дозволило їй досягти краших результатів. Однак сучасне адміністративне право України й Іспанії стає усе більше схожим, адже воно базується на спільних иінностях СС та стандартах НАТО. Визначено, що зародження адміністративного права в російській імперї здійснювалось під безпосереднім впливом німецького адміністративного права. Адже значна частина професорів у російській імперії були німецького походження. Не була винятком із цього правила і юриспрудениія. Це сталося в кіниі XIX - на початку XX століття, коли в російській імперіӥ адміністративне право почало поступово витісняти полічейське. З’ясовано, що на початку свого зародження адміністративне право Іспанії увібрало у себе положення класичного адміністративного права Франиї початку ХІХ століття. Адміністративне право України - положення російського адміністративного права, яке у свою чергу будувалось на положеннях німецького адміністративного права початку XX століття. В Україні в період 1932-1933 років радянський режим заморив голодом більше п'яти з половиною мільйонів україниів. Це йому вдалось зробити з погляду права, тому що грубо порушувалось право власності, коли в прочесі колективізації було вилучено в українських селян майно та земля. А потім у створених на иих землях колективних господарствах (колгоспах) із застосовуванням насилля був вилучений увесь урожай. 3'ясовано, що об'єднує адміністративне право України й Іспанії в тридиятих - сорокових роках ХХ століття - це те, що адміністративно-правові норми забезпечували протиправні режими: в Україні - радянський, в Іспанії - начіонально-католииький Франко. Хоча важко з погляду сучасного розуміння називати ті загальнообов'язкові правила поведінки нормами права. I в першому, і в другому випадку че було протиправне адміністративне законодавство, яке грубо порушувало права і свободи людей.

Ключові слова: витоки адміністративного права, Європейський Союз, Іспанія, історичні і правові аспекти, компаративістична характеристика, стандарти НАТО, Україна.

Постановка проблеми. В умовах сьогодення більшість європейських держав входять чи мають бажання увійти до складу єдиної сім'ї - Європейського Союзу. Адже саме в такому союзі проявляються найкращі чинники демократії, верховенства права, соціального захисту громадян. До ЄС зараз прямує й український народ: Уряд підписав, а Парламент ратифікував Угоди про Асоціації між Україною і СС. Проте на цьому шляху Україну чекає ще багато викликів. Тому цікавим і водночас повчальним у цьому аспекті буде аналіз досвіду демократичної, правової держави, яка порівняно недавно розпочала шлях до демократії, - Іспанії, здійснення компаративістичної характеристики адміністративного права України та Іспанії.

Огляд останніх досліджень. До теорії і практики компаративістики звертали свої наукові погляди деякі вітчизняні вченіадміністративісти. Серед них слід виділити В. Аверянова, С. Бандуру, О. Бандурку, B. Галунька, О. Кресіна, О. Кузьменко, Ю. Лемішко, Є. Павліченко, О. Погрібного, А. Саідова, О. Тихомирова, К. Шенбергера та ін. Проте вони безпосередньо проблематикою компаративістичного аналізу адміністративного права України й Іспанії не займалися, а зосереджували увагу на більш загальнихспеціальних чи суміжних викликах.

Мета статті полягає в тому, щоб на основі теорії адміністративного права України та Іспанії, національних законодавств, думок із цієї проблематики вчених у галузі адміністративного права виявити, проаналізувати історичні і правові аспекти витоків адміністративного права України й Іспанії та здійснити ї компаративістичну характеристику. 
Виклад основного матеріалу. Насамперед треба звернути увагу на те, що як адміністративне право Іспанії, так і адміністративне право України розвивалось у межах романогерманської правової сім'ї, континентальної Європи. У ній, як відомо, основним джерелом права є норма права, а зовнішнім її виразом - адміністративно-правові акти. Однак у витоках адміністративного права цих держав існують і значні відмінності.

По-перше, адміністративне право Іспанії із самого зародження увібрало в себе усі класичні положення французької моделі адміністративного права ще на початку XIX століття. Більш того, деякий вплив на розвиток адміністративного права Іспанії мав й англійський його варіант [1].

Українському адміністративному праву пощастило менше. На відміну від іспанських земель, українські ніколи не були під впливом Франції. Навіть під час російського походу 1812 року війська Наполеона не заходили на територію України. Адміністративне право України почало зароджуватися на століття пізніше, ніж в Іспанії, і в процесі входження українських земель до складу російської імперії.

У свою чергу зародження адміністративного права в російській імперії здійснювалось під безпосереднім впливом німецького адміністративного права. Адже значна частина професорів у російській імперії були німецького походження. Не була винятком із цього правила і юриспруденція. Це сталося наприкінці XIX - на початку XX століття, коли в російській імперії адміністративне право почало поступово витісняти поліцейське. Як стверджували вчені-адміністративісти тієї доби, поліцейське право забезпечуе потреби поліцейської держави, а адміністративне право - потреби правової держави [2].

Іншими словами, положення класичного французького адміністративного права, на відміну від Іспанії, потрапили в Україну не безпосередньо, а трансфером ланцюга, через переломлення їх у теорії і практиці німецького адміністративного права, що стало основою для російського адміністративного (поліцейського) права та поширення останнього на терени України, більшість територій якої входила до складу російської імперії. При цьому треба зазначити, що такі провінції України, як Галичина та Буковина, до 1918 р. входили до складу Австро-Угорської імпеpiï, на теренах якої діяло майже класичне німецьке адміністративне право.

Таким чином, на початку XX століття за основу нової галузі права - адміністративного права України - було взято виділення та подальший розвиток зі сфери державного (конституційного) права положень щодо внутрішнього публічного управління, куди вписалися норми поліцейського права, що відповідали вимогам правової держави верховенству права й підпорядкуванню державного управління закону [3, с. 18].

Отже, від самого зародження адміністративне право Іспанії увібрало у себе положення класичного адміністративного права Франції початку XIX століття, а адміністративне право України - положення російського адміністративного права, яке у свою чергу будувалось на положеннях німецького адміністративного права початку XX століття.

По-друге, в період 1917-1920 рр. в Україні тривав трагічний період національновизвольних змагань, який з погляду адміністративно-правової науки характеризується прогресивними намаганнями різних урядів (Центральна Рада Української Народної Республіки, Гетьманат Української держави, Директорія Української народної республіки) втілити в життя кращі вітчизняні та європейські напрацювання теорії адміністративного права. Одним із найбільших здобутків у галузі адміністративно-правової практики була поява в Україні адміністративної юстиції. Так, утворений в Українській народній республіці генеральний Суд мав у своєму складі адміністративний відділ (за правління гетьмана Павла Скоропадського перетворений на генеральний адміністративний суд). А в часи Директорії було відновлено діяльність цього суду у складі генерального суду. Як навчальна дисципліна адміністративне право посіло важливе місце й у навчальному процесі українських вищих навчальних закладів [3, с. 19].

На жаль, у листопаді 1920 р. армія Директорії Української народної республіки, програвши війну більшовикам, залишила територію України. Влада в державі цілком перейшла до рук більшовиків [3, с. 19]. Вони шляхом обману українського селянства та терору у 1922 р. утворити Радянський Союз (радянську імперію), до складу якої на правах федерації увійшла українська держава. У перші десятиліття входження України до складу Радянського Союзу адміністративне право на «легальному положенні» існувало лише до 1928 р., потім - до 1937 р. - воно було під повною забороною. Радянський режим замінив суспільні відносини, які мали регулюватися адміністративно-правовими нормами, кримінальним правом [3, с. 19]. Це призвело до того, що сотні тисяч осіб були розстріляні та мільйони українців засуджені і заслані в тюрми і концентраційні колонії за формальні проступки, які за теорію природ- 
нього права максимум дотягували до рівня адміністративної відповідальності.

$\mathrm{y}$ цей самий час в Іспанії також відбуваються складні політичні події. Хоча в роки Першої світової війни Іспанія дотримувалась нейтралітету, проте невдалі колоніальні війни, зростаючий вплив лівих та загальноєвропейська економічна депресія призводить Іспанію до урядової кризи, яка закінчується державним переворотом. Генерал Примо де Рівера в 1923 р. за підтримки короля встановлює диктатуру. Диктатор нав'язує тоталітарну владу уряду, яка витісняє політичні свободи та популістські вимоги на користь економічного відновлення. Це приводить до деякої політичної й економічної стабілізації в Іспанії [4].

Отже, незважаючи на складну ситуацію в період з 1917 по 1930 рр. як в Україні, так і в Іспанії, загальна ситуація у першій була більш трагічна, оскільки українська держава не змогла відстояти свою незалежність, а їі адміністративне право було під забороною, що привело до неправового з погляду теорії природного права позбавлення людей життя та свободи.

По-третє, по-своєму трагічним для кожного із народів був період тридцятих та сорокових років ХХ століття. В Україні в період 1932-1933 років радянський режим заморив голодом більше п'яти 3 половиною мільйонів українців. Це йому вдалось зробити 3 погляду права тому, що грубо порушувалась право власності, коли в процесі колективізації було вилучено в українських селян майно та земля. А потім у створених на цих землях колективних господарствах (колгоспах) із застосовуванням насилля був вилучений увесь урожай. А люди, які не мали що їсти, не змогли покинути зону голоду, тому що не мали паспортів, а виїзд за межі колгоспу без дозволу керівництва та паспорту в той час вважався злочином. В Україні та у більшості демократичних держав ці події були визнані геноцидом українського народу, який організував СРСР. Крім того, не треба забувати про злочини радянського режиму проти українського народу в період Другої світової війни, коли в результаті примусової мобілізації та використання солдат українського походження як «живого м'яса» на фронтах загинуло не менш ніж три мільйонів вояків та більше тринадцяти мільйонів мирних українців. Останні були кинуті напризволяще радянською владою, яка попередньо вилучила у них чи знищила усі запаси їжі та промислове обладнання [5].

Трагічним цей період був і для Іспанії. Після виборів 1931 р. президентом призначається ліберальний лідер Нісето Алкала
Замора. Король Альфонсо XIII залишає Іспанію. Проголошується республіка. Але політична стабільність триватиме недовго. У 1933 р. правоцентристська партія здобуває більшість у Кортесах, і у відповідь на це відбуваються революції в Каталонії та Астурії. Нарешті, у 1936 році ліва коаліція знову виграє вибори, а Мануель Азанья стає президентом республіки. Перший уряд Азани розпочинає амбітний проект реформ, оголосивши політичну амністію, розпочавши глибоку аграрну реформу та надаючи автономію Каталонії, провінціям Баска та Галіції. У відповідь на це військовий гарнізон Мелільі на чолі з генералом Франко розпочинає пуч, тим самим розпаливши громадянську війну в Іспанії. У 1939 р. опір республіканського уряду, який укрився в Каталонії та Мадриді, було подавлено. Багато іспанців пішли у вигнання. Війна закінчується жахливо: 400 тис. загиблих, 200 тис. страчених режимом Франко після війни. Більше як мільйон іспанців потрапили до в'язниць або трудових таборів за політичні переконання. Іспанія 36 років перебувала під національнокатолицькою диктатурою та у глибокій соціально-економічній кризі [4].

Адміністративне право України й Іспанії в 30-х - 40-х роках XX століття, на жаль, об'єднує те, що адміністративно-правові норми забезпечували протиправні режими: в Україні - радянський, в Іспанії - національно-католицький Франко. Хоча важко 3 погляду сучасного розуміння називати ті загальнообов'язкові правила поведінки нормами права. I в першому, і в другому випадку це було протиправне адміністративне законодавство, яке грубо порушувало права і свободи людей.

По-четверте, в різний період почалось відновлення (створення) правового адміністративного права в Україні і Іспанії. Процес демократизації, одночасно й відновлення (побудови) адміністративного права на засадах верховенства права розпочався в Іспанії після смерті Франко (1975). Однак ще в 1969 р. Франко оголосив своїм наступником принца Хуана Карлоса з династії Бурбонів, онука короля Альфонса XIII, який очолив державу як король Хуан Карлос I. У 1976 р. були відновлені політичні права - дозволені політичні мітинги і легалізовані демократичні політичні партії. У 1978 р. парламент ухвалив нову конституцію, яка була схвалена на загальному референдумі [11].

Процес переходу до демократії в цілому завершився в середині 1980-х років. Одночасно Іспанія починає тісніше співпрацювати із західними країнами в економічній і політичній сферах. У 1992 р. Іспанія рати- 
фікувала договір про утворення СС. Інтеграція Іспанії з країнами Західної Свропи і політика відкритості зовнішньому світу гарантували захист демократії від військових переворотів, а також забезпечували приплив іноземних інвестицій [6].

В Україні демократичні та державотворчі переміни розпочалися із запізненням на 16 років порівняно з Іспанією. У 1991 р. Парламент прийняв Акт, в якому було проголошено незалежність України та створення самостійної української держави. У ньому було визначено, що на території України мають чинність виключно Конституція і закони України [7]. А в 1996 р. була прийнята Конституція України, в якій визначено, що Україна - суверенна і незалежна, демократична, соціальна, правова держава [8]. 3 того часу розпочалося і нова ера для українського адміністративного права Воно наповнилось людиноцентристською ідеологією [9] як основою реформування з метою досягнення цінностей ЄС та стандартів НАТО. В умовах сьогодення усі сфери суспільного життя приводяться до вимог Угоди про асоціацію між Україною та Свропейським Союзом (2014), а в Конституції України прямо підтверджено європейську ідентичність Українського народу і незворотність європейського та євроатлантичного курсу України [8]. Іншими словами, українська демократія і теорія адміністративного права інтенсивно наздоганяють Іспанію.

\section{Висновки}

В останні сто років Іспанія й України пройшли складний і дещо схожий шлях державного будівництва та розвитку теорії і практики адміністративного права. Однак Іспанія розпочала його на шістнадцять років раніше й у більш слушний момент. Це дозволило їй досягти кращих результатів. Однак сучасне адміністративне право України й Іспанії стає усе більше схожим, адже воно базується на спільних цінностях $Є С$ та стандартах НАТО.

\section{Список використаних джерел:}

1. Eduardo Gamero Casado, Severiano Fernández Ramos. Manual Básico De Derecho Administrativo. Sexta Edición. Editor: Tecnos (Grupo Anaya, S.A.), 2009. No De Páginas: 661.
2. Єлістратов А.І. Адміністративне право : лекції / ред. та упоряд. В.В. Галунько, С.В. Діденко. Херсон : ВАТ ХМД, 2007. 146 с.

3. 43 Галунько В.В., Курило В.І., Короєд С.О. та ін. Адміністративне право України. T.1. Загальне адміністративне право : навчальний посібник / В.В. Галунько, В.І. Курило, С.О. Короєд, О.Ю. Дрозд, І.В. Гиренко, О.М. Єщук, І.М. Риженко, А.А. Іванищук, Р.Д. Саунін, I.M. Ямкова ; за ред. проф. В.В. Галунька. Херсон: Грінь Д.С., 2015. 272 с.

4. Resumen histórico: El siglo XX en España. University of Pennsylvania School of Arts and Sciences. 2018. URL: http://ccat.sas.upenn.edu/ romance/spanish/219/11sigloxxespana/resumen. html (дата звернення: 27.12.2019).

5. Скільки втратила Україна в Другій світовій війні. 2014. URL: https://zbruc.eu/node/ 28501 (дата звернення: 27.12.2019).

6. La transición política. La Constitución de 1978 y el Estado de las Autonomías. 2005. http://www.historiasiglo20.org/HE/16a-1.htm (дата звернення: 17.01.2020).

7. Про проголошення незалежності України : Постанова Верховної Ради Української РСР від 24.08.1991 № 1427-XII. Відомості Верховної Ради України (ВВР). 1991. № 38. С. 502.

8. Конституція України. Відомості Верховної Ради України. 1996. № 30. Ст. 141.

9. Авер'янов В. Людиноцентристська ідеологія як основа реформування українського адміністративного права в умовах інтеграційного процесу. Держава та регіони. Серія «Право». 2010. Вип. 2. С. 87-92.

10. Угода про асоціацію між Україною, з однієї сторони, та Європейським Союзом, Європейським співтовариством з атомної енергії і їхніми державами-членами, з іншої сторони / Верховна Рада України. 2014. URL: https://zakon.rada.gov.ua/ laws/show/984_011/card6\#Public (дата звернення: 17.01.20ㄹ).

11. La Constitución española de 1978. http://www.congreso.es/docu/constituciones/ 1978/1978 cd.pdf (дата звернення: 17.01.2020).

12. Miguel Sánchez Morón. Derecho Administrativo. Parte General. Novena Edición. Editorial: TECNOS (GRUPO ANAYA, S.A.), 2013. № de páginas: 960 .

13. Eduardo Gamero Casado. Manual Básico De Derecho Administrativo. Sexta Edición. Editor: Tecnos (Grupo Anaya, S.A.), 2009. № De Páginas: 661.

14. Eduardo García De Enterría. Curso De Derecho Administrativo. Decimoquinta Edición. Editor: Thomson Reuters (Legal) Limited / Civitas, 2011. El Libro Tiene 872 Página. 
The article compares the historical and legal aspects of the origins of the administrative law of Ukraine and Spain. It has been revealed and summarized that in the last hundred years Spain and Ukraine have gone through complex and somewhat similar paths of state-building and development of the theory and practice of administrative law. However, Spain started it sixteen years earlier and at a better time (1975). This allowed her to achieve better results. However, the modern administrative law of Ukraine and Spain is becoming increasingly similar as it is based on common EU values and NATO standards. It was determined that the emergence of administrative law in the Russian Empire was derived from the direct influence of German administrative law. After all, a large number of professors in the Russian Empire were of German descent. Jurisprudence was no exception to this rule. This happened in the late 19th and early 20th centuries, when administrative law in the Russian empire gradually replaced the police. It was found that, at the beginning of its birth, administrative law in Spain incorporated the provisions of classical administrative law in France in the early nineteenth century. Administrative law of Ukraine - the provisions of Russian administrative law, which in turn was based on the provisions of German administrative law in the early twentieth century. In Ukraine in the period 1932/1933, the Soviet regime starved more than five and a half million Ukrainians. He succeeded in doing so from the point of view of law because it violated property rights when property and land were confiscated from Ukrainian peasants in the process of collectivization. And then in the collective farms (collective farms) created on these lands with the use of violence the whole crop was withdrawn. It is proved that unites the administrative law of Ukraine and Spain in the thirties of the forties of the twentieth century is that administrative and legal norms were provided by the unlawful regimes: in Ukraine by the Soviet, in Spain by the national-Catholic Franco. Although it is difficult in modern terms to call these compulsory rules of conduct rules of law. In the first and second cases, it was unlawful administrative legislation that grossly violated the rights and freedoms of people.

Key words: comparative characteristic, European Union, historical and legal aspects, NATO standards, origins of administrative law, Spain, Ukraine. 